\title{
EVALUATION OF DEVELOPMENT OF COOPERATION IN SOUTH BOHEMIAN MUNICIPALITIES IN THE YEARS 2007-2014
}

Jiř́ Dušek ${ }^{1}$

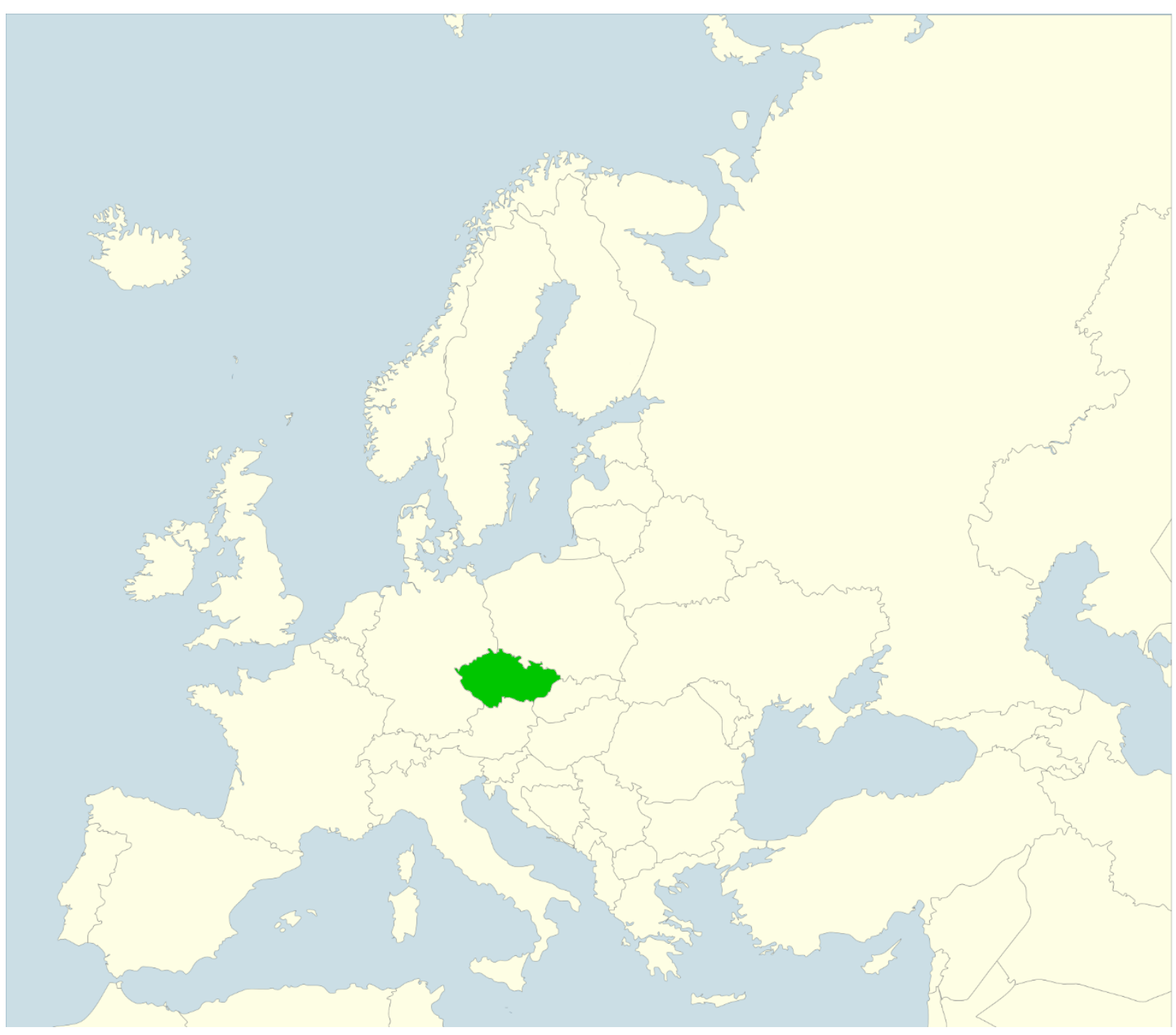

1 Ing. Jiři Dušek, Ph.D., Management and Marketing Services Department, College of European and Regional Studies, Žižkova tř. 6, České Budějovice, 370 11, Czech Republic; email: jiridusek@centrum.cz 
Abstract: The article presents results of the research of cooperation of municipalities in the South Bohemian Region, focused on the analysis of forms and means of cooperation between 2007 and 2014. The published results are part of an internal research that lasted for many years, the goal of which was both to analyse the development of cooperation of municipalities in the studied region and to identify the prerequisites and barriers of all cooperative relations. The research was done on a sample of 623 South Bohemian municipalities in the period of 2007-2010 and 20132016, the obtained data was processed using descriptive statistics and multidimensional statistical methods, and the results show an almost $20 \%$ increase in the means of municipal cooperation across the entire South Bohemian Region. Based on the respective means of cooperation, National Healthy Cities Network of the Czech Republic saw the biggest growth, amounting to $+3.275 \%$ between 2007 and 2014 . Participation in local action groups, where the total of 580 municipalities are already engaged, increased by $32.12 \%$. Although less dynamic, this growth is much more important, as it significantly contributes to the development of rural areas and their absorption abilities, mainly as regards financial resources from the national and European sources. However, fragmented means of municipal cooperation is a current problem of cooperation of municipalities, leading to the disintegrated power of the respective municipalities.

Key words: cooperation of municipalities, micro-region, local action groups, regional development

Souhrn: Článek přináší výsledky výzkumu spolupráce obcí v Jihočeském kraji, který se se zaměřuje na analýzu změn forem a způsobů spolupráce obcí v letech 2007 a 2014 v Jihočeském kraji. Publikované výsledky jsou částí dlouholetého interního výzkumu, jehož cílem bylo analyzovat nejen vlastní vývoj spolupráce obcí ve zkoumaném regionu, ale i identifikovat předpoklady a bariéry všech kooperativních vztahů. Výzkum byl realizován na vzorku 623 jihočeských obcí v letech 2007-2010 a 2013-2016, získaná data byla zpracována popisnou statistikou i vícerozměrnými statistickými metodami, přičemž výsledky ukazuji skoro $20 \%$ nárůst způsobů spolupráce obcí napřič celým Jihočeským krajem. Na bázi jednotlivých způsobů kooperace došlo v letech 2007-2014 k největšímu nárůstu u Národní sítě Zdravých měst ČR $0+3,275 \%$. Daleko podstatnější, byt' méně dynamický růst, je 32,12 \% vzestup zapojení do místních akčních skupin, kde je již zapojeno celkem 580 obcí, což výrazně napomůže rozvoji venkova a jeho absorpčním schopnostem, zvlášt' pokud jde o finanční prostředky z národních a evropských zdrojů. Aktuálním problémem spolupráce obcí je však fragmentace způsobů obecní spolupráce a tím i rozměňování sil jednotlivých obcí.

Klíčová slova: spolupráce obcí, mikroregion, místní akční skupiny, regionální rozvoj

\section{Introduction}

Cooperation is an important relationship in all areas of human activity. It makes it possible to achieve essential goals in an easier and more efficient way. In a number of cases, it is not possible to achieve one's goal without any cooperation at all. It is important not just in interpersonal relationships, but also in activities and communication of various subjects. The current conception of regional politics as an activity, which is supposed to help diminish differences between the development levels of the respective regions and ensure their harmonious development, accentuates and requires the necessity for municipalities to cooperate on the development of the respective area (Galvasová, 2007: 11). It is very important for all participants to find such a system of cooperation which will enable them to reach the goals they have set in the best possible way. Improving the respective elements of cooperation is a long-term process helping to 
support the development of the respective regions. It enables a better and more efficient way to reach the desired results. On the other hand, it is a fact that in a number of cases, cooperation is not possible for various reasons (Dušek, 2013: 330). Local governments have a natural tendency to cooperate with each other to overcome their weak points and deal with their insufficiency, which is usually caused by the small size of the municipality (Leemans, 1970, Rakar, Tičar, Klun, 2015). The role of cooperation of municipalities as an important development factor is confirmed by Bartholomeeussen, 2001, Žárska, 2007, Hulst and Van Montfort, 2007, Wokoun, 2008, Frick and Hokkeler, 2008, Holeček, 2009, Rose, 2010, Schulitz and Knoblauch, 2011, Klein, 2012, Nelles, 2013, Richter, 2013, Huber, 2014, Bel, Warner, 2015, Teles, 2016a, 2016b, and others.

Following major changes of the settlement structure in the 1990s, the number of municipalities in the Czech Republic does not correspond to the number of municipalities in comparison with other European countries. The number of municipalities does not exceed 1,000 in most of them and the smallest municipalities often have more than 5,000 residents. Municipalities with 25,000 residents are no exception. In Sweden, for instance, there are only slightly more than 300 municipalities (Perlín, 1999: 91). In Europe, the same number of municipalities as in the Czech Republic is only in France and with regard to the population, also in Slovakia (138 towns and 2891 municipalities).

If we compare 1980, when population census revealed the smallest number of municipalities, with 2015, the biggest changes were seen in the category of municipalities with up to 199 residents $(+174.24 \%)$ and $200-499$ residents $(+30.68 \%)$. A major change was also recorded in municipalities with 10,000-19,999 residents (-11.54\%) and 50,000-99,999 residents (-7.65\%) due to their shift to a higher/lower category. In other categories, there were changes only in single $\%$ between 1980 and 2015. Nowadays, only 32\% of residents live in $93 \%$ of municipalities.

Tab 1. Number of municipalities in the Czech Republic in different size categories between 1921 and 2015. Source: Czech Statistical Office, 2013a, 2013b, 2015a, own calculations.

\begin{tabular}{|c|c|c|c|c|c|c|c|c|c|c|c|c|}
\hline $\begin{array}{l}\text { Size category } \\
\text { of } \\
\text { municipality }\end{array}$ & 1921 & 1930 & 1950 & 1961 & 1970 & 1980 & 1991 & 2001 & 2011 & 2013 & 2014 & 2015 \\
\hline $1-199$ & \multirow{2}{*}{6706} & 2056 & 4163 & 2018 & 1490 & 528 & 1328 & 1661 & 1492 & 1461 & 1455 & 1448 \\
\hline $200-499$ & & 5145 & 4204 & 3341 & 2805 & 1535 & 1955 & 2041 & 2015 & 2012 & 2001 & 2006 \\
\hline 500-999 & 2820 & 2635 & 1825 & 1876 & 1794 & 1345 & 1224 & 1280 & 1349 & 1356 & 1369 & 1365 \\
\hline 1000-1999 & 1194 & 1175 & 734 & 853 & 800 & 705 & 647 & 652 & 726 & 742 & 745 & 747 \\
\hline $2000-4999$ & 515 & 568 & 374 & 436 & 400 & 390 & 347 & 363 & 399 & 411 & 412 & 415 \\
\hline 5000-9999 & 116 & 112 & 91 & 115 & 120 & 136 & 131 & 130 & 138 & 140 & 140 & 141 \\
\hline 10000-19999 & 43 & 49 & 37 & 51 & 59 & 78 & 71 & 68 & 69 & 68 & 68 & 69 \\
\hline $20000-49999$ & 19 & 23 & 22 & 24 & 26 & 39 & 41 & 41 & 42 & 42 & 43 & 43 \\
\hline 50000-99999 & 0 & 1 & 5 & 8 & 13 & 17 & 17 & 17 & 16 & 16 & 15 & 14 \\
\hline $100000+$ & 4 & 4 & 4 & 4 & 4 & 5 & 7 & 5 & 5 & 5 & 5 & 5 \\
\hline Total & 11417 & 11768 & 11459 & 8726 & 7511 & 4778 & 5768 & 6258 & 6251 & 6253 & 6253 & 6253 \\
\hline
\end{tabular}

Tab 2. Paradox of the number of municipalities and the number of residents. Source: Czech Statistical Office, 2015b, own calculations.

\begin{tabular}{|c|c|c|c|c|}
\hline Size category of municipality & Number of $n$ & nicipalities & Number & sidents \\
\hline up to 499 residents & $55.24 \%$ & \multirow{4}{*}{$92.76 \%$} & $7.92 \%$ & \multirow{4}{*}{$32.31 \%$} \\
\hline 500-2,999 residents & $37.52 \%$ & & $24.39 \%$ & \\
\hline 3,000 and more residents $*$ & $7.24 \%$ & & $67.69 \%$ & \\
\hline Total & $100.00 \%$ & & $100.00 \%$ & \\
\hline
\end{tabular}

* Currently, as defined by the municipal law of the Czech Republic, a municipality with more than 3,000 residents is classified as a town by the chairperson of the Chamber of Deputies upon the government's proposal. A municipality can get a status of a town regardless of these criteria, if it can prove in a plausible way that it used to have this status in the past. 
A fragmented structure of municipalities, i.e. a large number of small and very small municipalities, has become a matter of many discussions in Europe in the past few years (e.g. Bennett, 1993, 1997, Blažek, 2004, Lidström, 1998, Sager, 2005, Sciandra, 2011, Lacerda, Ribeiro, 2014, or Klimovský, Mejere, Mikolaityte, Pinterič, Saparniene, 2014). According to Bink, 2011: 18, it is often criticized as regards the social and economic development of rural areas, the stability of elected authorities of small municipalities, their financial management, the quality of their administrative acts, sticking to law etc. It is true that relative costs of the local government performance and provided services decrease with the size of municipality, so these functions are cheaper. Joining municipalities does not reduce the costs of building infrastructure and the settlement structure remains the same (economic arguments are not to be overestimated, see more; Gillette and Skeelb, (2016). Many savings can be reached by mere cooperation (e.g. within associations of municipalities), which is also observed by Ryšavý (2006), who sees building a cooperation network among rural areas and towns, mainly medium-sized centres, as fundamental and also stresses the importance of interconnected economic activities of small settlements in rural areas.

If we sum up studies done in recent years, however, we cannot reach a general conclusion regarding the support of merging municipalities into bigger entities at the expense of cooperation between municipalities or vice versa, because the opinions of experts differ on this issue. For instance, Vajdová, Čermák, Illner, 2006, state in their study that big municipalities can manage their economic, social and regional development better than small municipalities. Furthermore, bigger municipalities are less threatened by fluctuations in inner and outside conditions for its functioning than small municipalities. Better predispositions for the development of cooperation in bigger municipalities are also shown as examples in Greece, Norway and Spain by Sørensen, 2007, Bel, Fageda, Mur, 2013, Hazakis, loannidis, 2014, Denters, et al, 2016, and others. On the other hand, other authors, emphasize better predispositions and more intensive cooperation in the case of smaller municipalities - see Urbanová, 2015, or Wiberg, Limani, 2015.

The view of cooperation of municipalities is not equivocal in professional and political circles as it often reflects local specifics, different historical development and experiences etc. (e.g. Poland, Scandinavia vs. Czech Republic, Slovak Republic, Hungary, France). British sociologist and political scientist, Michael Keating, who was concerned with the link between the performance and effectiveness of public administration in the context of the size of municipalities, gathered a comprehensive set of arguments in favour and to the disadvantage of small municipalities, and when the positives and negatives of integration are to be evaluated, he recommends to consider the following four factors (Keating, 1995, p. 117-134):

$>$ the effectiveness factor - the relation between the size of a municipality and the relative price of services provided to citizens,

$>$ the local democracy factor - the relation between the size of a municipality and the democratic character of local politics,

$>$ the distributive justice factor - the relation between the size of a municipality, the tax burden on citizens and the level of services provided for citizens (a question of budget determination of taxes in the Czech Republic),

$>$ the development factor - the relation between the size of a municipality and the perspectives of its further development.

Other authors concerned with these issues include e.g. Swianiewicz, 2002, Halachmi, Boorsma, 2013, Teles, 2016a, etc. In their works, they reached the same conclusions as Keating, 1995, i.e. the results of expert research projects are not always equivocal in this area, like for example in the view of an optimum municipality size.

\section{Materials and methods}

The methodological procedure corresponds with the methods typically used in works focused on scientific research. It is based on using the latest theoretical knowledge gained by studying professional literature, research results and studies, journals and materials of the respective participants of regional development and from the author's personal experience. It is also based 
on searching for and assessing mutual relationships and connections which help to explain the given problem and on making and formulating adequate conclusions that arise from this analysis. As regards theory and methodology, the work indirectly follows the targets of several development and research projects controlled by the Ministry of Regional Development of the Czech Republic and the South Bohemian Region which the author took part in as a researcher and co-researcher in the past.

The focus of the work primarily on the South Bohemian Region is not accidental. As regards cooperation of municipalities, it is a region with the lowest density of population in the Czech Republic (63.37 residents $/ \mathrm{km}^{2}$ ) and a very fragmented municipal structure, which is a handicap that can be overcome by different means of cooperation of municipalities. The region has a convenient location, where various forms of cooperation of municipalities within European Territorial Cooperation (with Germany and Austria) are available in the south-west, cooperation with municipalities of the Central Bohemian Region (the second most developed region in the Czech Republic) is available in the north and cooperation with municipalities of the Highlands Region is available in the east, the Highlands Region being one of the poorest regions in the Czech Republic. From the historical point of view, these unique conditions led to the formation and development of a very wide range of different forms of cooperation of municipalities in the South Bohemian Region, some of which cannot be found in other regions at all, or to a very limited extent. As an area with a maximum number of different forms of cooperation is considered, the procedure of creating a model database of cooperation between municipalities can be applied on and transferred to any region of the Czech Republic.

In order that the intensity of cooperation of municipalities in a selected region could be assessed objectively, the author constructed an assessment model of cooperation of municipalities with the help of the quantification method. A quantitative expression of the dimension is the value of a synthetic marker called cooperation coefficient $\left(\mathrm{C}_{\mathrm{C}}\right)$ calculated by the following formula (it is generally based on the previous research done by the author - for more information see Dušek, 2010: 87, but it is entirely adapted and modified according to the new classification of forms and means of cooperation of municipalities given in Table 4). The coefficient of cooperation in this contribution is used to demonstrate differences in the quality of cooperation among municipalities within individual regions. The coefficient of cooperation of a given area is calculated as an average of individual coefficients of cooperation found in the studied area.

$$
C_{C}=\sum_{i=M C R}^{E G T C} V_{i}
$$

Tab 3. Definition of variables when calculating the cooperation coefficient $C_{c}$. Source: The author's own work

\begin{tabular}{|l|l|}
\hline Variable & Definition of variable \\
\hline$V_{\text {MCR }}$ & member of micro-regions \\
\hline$V_{U T M S B R}$ & member of the Union of Towns and Municipalities of the South Bohemian Region \\
\hline$V_{\text {LAG }}$ & member of a local action group \\
\hline$V_{C L}$ & member of clusters \\
\hline$V_{\text {NHCN }}$ & member of the National Healthy Cities Network of the Czech Republic \\
\hline$V_{U T M C R}$ & member of the Union of Towns and Municipalities of the Czech Republic \\
\hline$V_{\text {ALGCR }}$ & member of the Association of Local Governments of the Czech Republic \\
\hline$V_{\text {CIC }}$ & the municipality is a member of cross-border impulse centres \\
\hline$V_{E}$ & the municipality is a member of Euro-regions \\
\hline$V_{\text {EGTC }}$ & the municipality participates in the European Grouping of Territorial Cooperation \\
\hline$i$ & means of cooperation of municipalities \\
\hline
\end{tabular}


Tab 4. Forms and means of cooperation of municipalities in the Czech Republic. Source: The author's own work

\begin{tabular}{|c|l|c|}
\hline Form of cooperation & Means of cooperation & Availability of data \\
\hline \multirow{4}{*}{$\begin{array}{c}\text { Inter-municipal cooperation on a } \\
\text { regional level }\end{array}$} & Micro-regions & yes \\
\cline { 2 - 3 } & Joint participation in business corporations & no \\
\cline { 2 - 3 } $\begin{array}{c}\text { Cooperation of municipalities with } \\
\text { subjects in the area }\end{array}$ & Contract for the fulfilment of a particular task & yes \\
\cline { 2 - 3 } & Specific forms of cooperation & yes \\
\cline { 2 - 3 } & Local action group & no \\
\cline { 2 - 3 } $\begin{array}{c}\text { National structures of inter- } \\
\text { municipal cooperation }\end{array}$ & Union & no \\
\cline { 2 - 3 } & Clusters & yes \\
\cline { 2 - 3 } & Specific forms of cooperation & no \\
\hline & National Healthy Cities Network of the Czech Republic & yes \\
\cline { 2 - 3 } & Union of Towns and Municipalities of the Czech Republic & yes \\
\cline { 2 - 3 } & Association of Local Governments of the Czech Republic & yes \\
\cline { 2 - 3 } $\begin{array}{c}\text { Cooperation of municipalities with } \\
\text { subjects from other countries }\end{array}$ & Specific forms of cooperation & no \\
\hline & Cross-border impulse centres (CBICs) & yes \\
\cline { 2 - 3 } & Euro-regions & yes \\
\cline { 2 - 3 } & European Groupings of Territorial Cooperation & yes \\
\cline { 2 - 3 } & Twin towns and sister cities and municipalities & no \\
\cline { 2 - 3 } & Specific forms of cooperation & no \\
\hline
\end{tabular}

Note: As a suitable database or other source of data does not exist, it was not possible to analyse all forms of contemporary cooperation of municipalities within the studied region. It would be possible to collect some missing data, but the data would be very fragmented and the process would be extremely time-consuming and expensive.

As regards the chance that towns and municipalities have to get engaged in the respective forms and means of cooperation, municipalities can take part in multiple forms of cooperation, for example, within micro-regions ${ }^{2}$, Euro-regions and cross-border impulse centres. There are partial limitations that should not have an impact on the overall activity of municipalities, however. Local action groups cannot include towns with the population of more than 25,000 or an unfavourable location of a municipality within a region may limit its cooperation with subjects from other countries. However, this can be compensated by more intensive engagement of the municipality in micro-regions or other forms of cooperation.

The construction of the formula is based on new typology of means and forms of cooperation of municipalities in the Czech Republic designed by the author (for more information see Table 4), where the formula includes all statistically available forms of cooperation within the studied South Bohemian Region (the formula can be easily modified to suit a different region or even a country). These forms were assigned the same importance 1.0, although their significance for the development of the region varies. The reason for this decision was the fact that municipalities join micro-regions or local action groups first and participate in other "above-standard" types of cooperation later. Rather than the significance of the respective elements, the importance reflects the relevance of the database. In practice, the cooperation coefficient has a better declarative value in determining equal importance. It is apparent at first sight how many times a town or a municipality has participated in any form of cooperation in the studied region. The author has presented this way of assessing cooperation of municipalities at a large number of expert forums both in the Czech Republic and abroad, and it was experimentally verified in the South Bohemian Region in 2009 and in the Central Bohemian Region in 2011. Then the author focused on making the data collection more precise, publishing the results and their dissemination in practice (the assessment of cooperation of municipalities in this form was used, e.g. by the Union of Municipalities of the Jilemnice District in 2015).

A problem when studying cooperation of municipalities is the fact that there are no relevant sources or they are inaccurate. When specifying a concrete shape of the research with regard to the need of verifying some theoretical findings stated in literature search, the author decided to

\footnotetext{
2 The term micro-region is in Czechia sometimes (incorrectly) used for voluntary associations of municipalities in the sphere of self-governmental competences.
} 
postulate the following hypotheses, the validity or invalidity of which will subsequently be verified on the example of the South Bohemian Region:

1. The most widely spread kinds of cooperation between municipalities in the studied region are - due to financial support from domestic and European sources - micro regions and local action groups. This presupposition is based on both own and German research of barriers of cooperation between municipalities (see Schnabel, 2012). The biggest barrier of cooperation stated by municipalities is the lack of financial means. It can thus be assumed that financially better supported kinds of cooperation will attract more municipalities.

2. Cooperation between municipalities develops more intensively only in certain development centres / axes of a region, intensity on the periphery is significantly lower. According to Holeček, 2009, uneven development of a region is caused by the fact that every area has a unique combination of certain characteristics which create potential for development. The usability of this potential depends on activity of citizens, location of an area and the financial means that are available.

\section{Research results}

The settlement structure of the Czech Republic is characterised by a large number of small municipalities and the South Bohemian Region is no exception here. On the one hand, it is a region with the lowest density of population in the entire Czech Republic. On the other hand, as regards the number of municipalities, it is on the 4th place among all regions of the Czech Republic. The fragmented settlement structure and the growing demands of participants of regional development can cause many problems. Cooperation of municipalities can be a significant step in overcoming these problems, no matter if it relates to providing the basic functions of municipalities and their development or to getting financial resources for example from the European funds, which would not be possible for a subject acting on its own.

The development of cooperation of municipalities in the South Bohemian Region between 2007 and 2014 was influenced by a lot of factors, especially by the influx of European financial resources and resources from the national budget. Also, some current topics played an important role before communal elections in 2010 and 2014 (e.g. Car-Free Day and public transport free of charge on $22^{\text {nd }}$ September, etc.). The largest change in \% was recorded by the National Healthy Cities Network of the Czech Republic (+3,275\%). The reason is a low initial state in 2007 and certain popularity of the respective areas. Means of cooperation which were significantly influenced by the accessibility of financial resources include local action groups, cross-border impulse centres and Euro-regions. However, cross-border impulse centres and Euro-regions were gradually influenced by the lack of financial resources caused by the fact that funds from the grants from the programming period of 2004-2006 were used up at the beginning of the programming period of 2007-2013. As a result, the network collapsed and the cross-border impulse centres ceased their activities (-90.6\% participation of municipalities) and the interest in being members of Euro-regions fell by $-28.5 \%$. Financial resources of the Rural Development Programme amounting to $€ 2.82$ billion made the interest in the membership in local action groups rocket (by $+32.12 \%$ in the South Bohemian Region), their number grew to approximately 180 in 2004-2013 and with a few exceptions, their scope of activity covers the entire area of the Czech Republic. Unfortunately, only 112 local action groups were selected to receive the financial support of the Rural Development Programme (12 from the South Bohemian Region), while other local action groups ( 5 from the South Bohemian Region) had the opportunity to get only symbolic hundreds of thousands of CZK to learn skills and knowledge in order to create an active local partnership focused on sustainable development of the region, which of course was not an adequate compensation for the programme and made the activities of some local action groups in the area of Český Krumlov and Tábor stop. As a result, "white spots" appeared on the map of cooperation of municipalities. As regards the absolute number of local action groups, they improved their position as the second most significant cooperation in the South Bohemian Region, following micro-regions. 
The last group of means of cooperation of municipalities includes entirely new or as yet unused means, where it is not possible to determine the \% of progress (e.g. clusters, Association of Local Governments of the Czech Republic, European Groupings of Territorial Cooperation), or means of cooperation, the change of which amounts only to single \% and where territorial saturation occurred in the past (micro-regions, Union of Towns and Municipalities of the South Bohemian Region, Union of Towns and Municipalities of the Czech Republic), so only slight progress or stagnation of these forms of cooperation can be expected in the future. All in all, the participation of municipalities in municipal cooperation increased by $20 \%$ between 2007 and 2014, while fragmentation of the respective form of cooperation became very apparent.

Tab 5. Development of the means of cooperation of municipalities in 2007-2014. Source: Author's own research

\begin{tabular}{|c|c|c|c|c|c|c|c|}
\hline 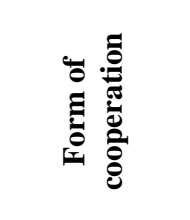 & 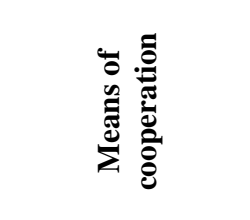 & 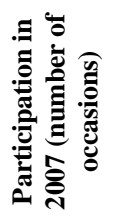 & 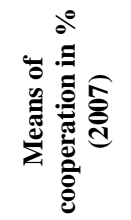 & 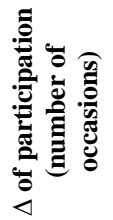 & 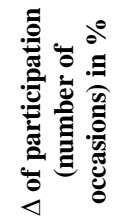 & 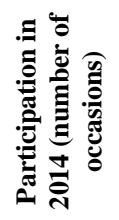 & 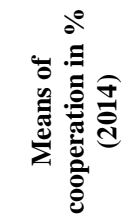 \\
\hline & Micro-regions & 721 & $39.18 \%$ & 40 & $5.55 \%$ & 761 & $34.94 \%$ \\
\hline $\begin{array}{l}\text { Inter- } \\
\text { municipal } \\
\text { cooperation on } \\
\text { a regional level }\end{array}$ & $\begin{array}{l}\text { Specific forms of } \\
\text { cooperation (Union } \\
\text { of Towns and } \\
\text { Municipalities of the } \\
\text { South Bohemian } \\
\text { Region) }\end{array}$ & 287 & $15.60 \%$ & 7 & $2.44 \%$ & 294 & $13.50 \%$ \\
\hline \multirow{2}{*}{$\begin{array}{l}\text { Cooperation of } \\
\text { municipalities } \\
\text { with subjects } \\
\text { in the area }\end{array}$} & Local action group & 439 & $23.86 \%$ & 141 & $32.12 \%$ & 580 & $26.63 \%$ \\
\hline & Clusters & 0 & $0.00 \%$ & 0 & - & 0 & $0.00 \%$ \\
\hline \multirow{3}{*}{$\begin{array}{c}\text { National } \\
\text { structures of } \\
\text { inter-municipal } \\
\text { cooperation }\end{array}$} & $\begin{array}{l}\text { National Healthy } \\
\text { Cities Network of } \\
\text { the Czech Republic }\end{array}$ & 4 & $0.22 \%$ & 131 & $3275.00 \%$ & 135 & $6.20 \%$ \\
\hline & $\begin{array}{l}\text { Union of Towns and } \\
\text { Municipalities of the } \\
\text { Czech Republic }\end{array}$ & 227 & $12.34 \%$ & 5 & $2.20 \%$ & 232 & $10.65 \%$ \\
\hline & $\begin{array}{l}\text { Association of Local } \\
\text { Governments of the } \\
\text { Czech Republic }\end{array}$ & 0 & $0.00 \%$ & 80 & - & 80 & $3.67 \%$ \\
\hline \multirow{3}{*}{$\begin{array}{l}\text { Cooperation of } \\
\text { municipalities } \\
\text { with subjects } \\
\text { from other } \\
\text { countries }\end{array}$} & $\begin{array}{l}\text { Cross-border } \\
\text { impulse centres }\end{array}$ & 32 & $1.74 \%$ & -29 & $-90.63 \%$ & 3 & $0.14 \%$ \\
\hline & Euro-regions & 130 & $7.07 \%$ & -37 & $-28.46 \%$ & 93 & $4.27 \%$ \\
\hline & $\begin{array}{l}\text { European Groupings } \\
\text { of Territorial } \\
\text { Cooperation }\end{array}$ & 0 & $0.00 \%$ & 0 & - & 0 & $0.00 \%$ \\
\hline \multicolumn{2}{|l|}{ Total } & 1840 & $100.00 \%$ & 338 & $18.37 \%$ & 2178 & $100.00 \%$ \\
\hline
\end{tabular}

When we assessed not only the means, but also the main 4 forms of cooperation of municipalities, the first cooperation partner was always another municipality, most often adjacent, so the form of cooperation of municipalities is on a regional level. The results are confirmed by the development of cooperation of municipalities itself and also by the research done on a representative sample of 263 municipalities within the project Regional Management as a Way to the Sustainable Development of Rural Regions, reg. n. WB-14-04, which assessed, besides other things, the importance of institutions/partners for the development of the region. However, this form has already been exhausted from the historical point of view and between 2007 and 2014 the growth of only $4.66 \%$.

According to respondents, other important partners include citizens, universities and the private sector, who gradually started to show itself in the dynamic increase in cooperation, first with other subjects in the area $(+32.12 \%)$, and then in the cooperation of regions within the national structures of cooperation of municipalities $(+93.51 \%)$. Contrary to the priorities of the European Union and a lot of tools intended to maintain balanced and sustainable development of European cross-border areas since 1990 (INTERREG, INTERREG II, Phare CBC, INTERREG III and IVC, operational programs of cross-border cooperation), they prove to be inefficient, unsystematic and 
unsustainable in the long run. The last fact is proven by the decreasing interest of municipalities in cooperation with the subjects of other countries $(-40.74 \%)$, caused by many barriers and compared with other forms of cooperation, also by its financial unattractiveness. Orientation only on cultural and sporting activities also plays its role, the cross-border cooperation is absolutely insufficient in the economic area and absolutely fails in this respect. It is not surprising that even respondents do not consider this form of cooperation to be prospective.

Tab 6. Development of the forms of cooperation of municipalities in the South Bohemian Region in 2007-2014. Source: Author's own research

\begin{tabular}{|c|c|c|c|c|c|c|}
\hline Form of cooperation & $\begin{array}{c}\text { Participation } \\
\text { in 2007 } \\
\text { (number of } \\
\text { occasions) }\end{array}$ & $\begin{array}{c}\text { Means of } \\
\text { cooperation } \\
\text { in \% } \\
\text { (2007) }\end{array}$ & $\begin{array}{c}\Delta \text { of } \\
\text { participation } \\
\text { (number of } \\
\text { occasions) }\end{array}$ & $\begin{array}{c}\Delta \text { of } \\
\text { participation } \\
\text { (number of } \\
\text { occasions) in } \\
\text { \% }\end{array}$ & $\begin{array}{c}\text { Participation } \\
\text { in 2014 } \\
\text { (number of } \\
\text { occasions) }\end{array}$ & $\begin{array}{c}\text { Means of } \\
\text { cooperation } \\
\text { in \% } \\
\text { (2014) }\end{array}$ \\
\hline $\begin{array}{c}\text { Inter-municipal } \\
\text { cooperation on a } \\
\text { regional level }\end{array}$ & 1008 & $54.78 \%$ & 47 & $4.66 \%$ & 1055 & $48.44 \%$ \\
\hline $\begin{array}{c}\text { Cooperation of } \\
\text { municipalities with } \\
\text { subjects in the area }\end{array}$ & 439 & $23.86 \%$ & 141 & $32.12 \%$ & 580 & $26.63 \%$ \\
\hline $\begin{array}{c}\text { National structures of } \\
\text { inter-municipal } \\
\text { cooperation }\end{array}$ & 231 & $12.55 \%$ & 216 & $93.51 \%$ & 447 & $20.52 \%$ \\
\hline $\begin{array}{c}\text { Cooperation of } \\
\text { municipalities with } \\
\text { subjects from other } \\
\text { countries }\end{array}$ & 162 & $8.80 \%$ & -66 & $-40.74 \%$ & 96 & $4.41 \%$ \\
\hline Total & $\mathbf{1 8 4 0}$ & $\mathbf{1 0 0 . 0 0 \%}$ & $\mathbf{3 3 8}$ & $\mathbf{1 8 . 3 7 \%}$ & $\mathbf{2 ~ 1 7 8}$ & $\mathbf{1 0 0 . 0 0 \%}$ \\
\hline
\end{tabular}

Based on the findings regarding the development of cooperation of municipalities, it is possible to build a pyramidal model of four levels showing the respective forms of cooperation of municipalities, as an analogy to Maslow's Hierarchy of Needs. The first two categories (from the bottom side) can be described as the basic forms of cooperation of municipalities saturating the elementary functions/needs of municipalities; the third and fourth category can be described as the categories of growth, which are not necessary for the implementation of the basic needs/functions but can enable to satisfy higher needs/functions (e.g. political). Generally, the forms of cooperation placed on the lower positions are more significant and their fulfilment, at least partial, is a presupposition for the formation of less pressing and developmentally higher forms of cooperation of municipalities. However, this classification cannot be accepted unconditionally. In some border regions, mutual bilateral relationships and cooperation existed in the past (e.g. České Velenice - Gmünd was a single town before 1919), and of course the tendency to cooperate with subjects of other countries is higher here than in other areas of the South Bohemian Region and the Czech Republic. As in the real Maslow Hierarchy model, some municipalities are motivated only by lower forms of cooperation of municipalities and do not have an ambition to implement higher forms of cooperation of municipalities which would shift their level as regards quality to another dimension in the long run. For example there are 18 municipalities (2.89\%) in the South Bohemian Region that focus exclusively on cooperation in micro-regions and local action groups. 


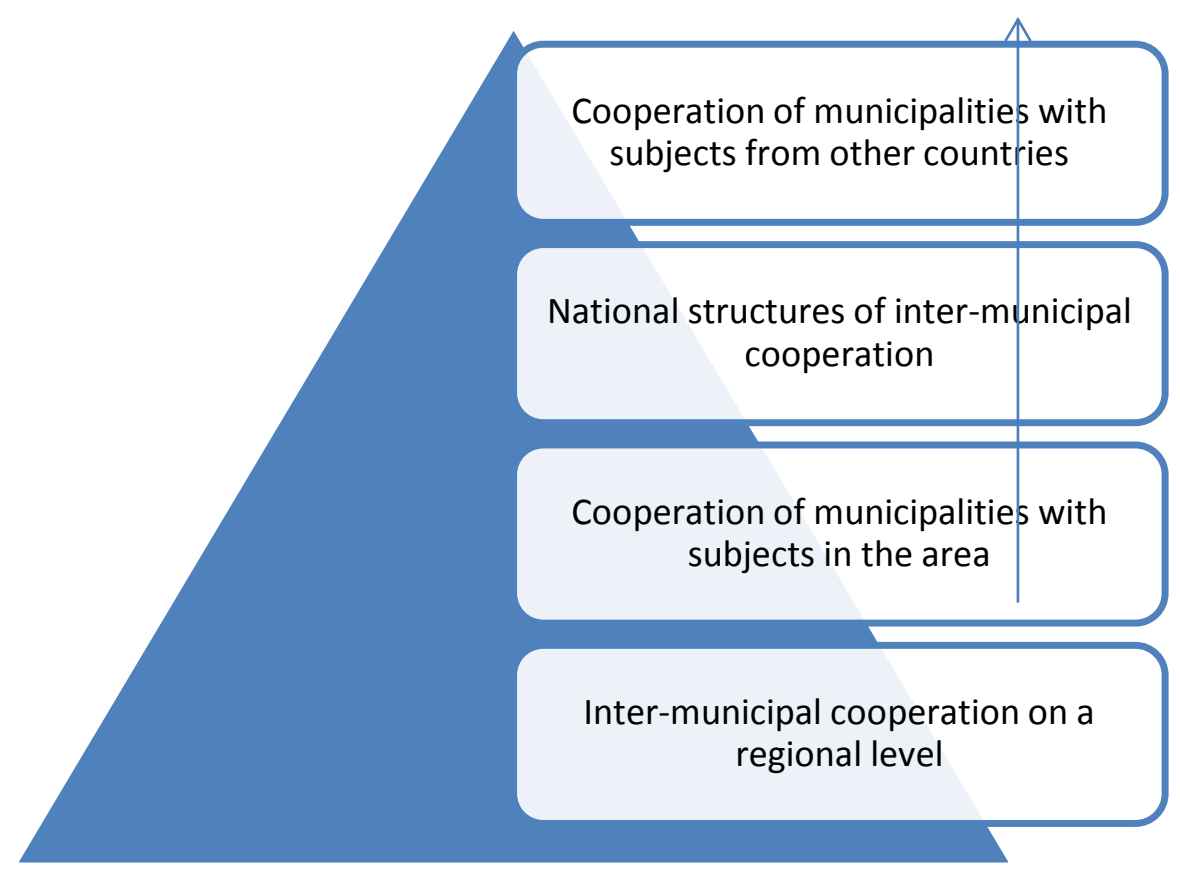

Fig 1. Pyramidal model showing the significance of the respective forms of cooperation of municipalities. Source: Author's own research

In the South Bohemian Region, despite a partial weakening, the most important form of cooperation at the moment is inclusion of towns and municipalities in micro regions $-34.94 \%$ of all forms of cooperation; in second place are local action groups at $26.63 \%$, which only confirms hypothesis No. 1 - which assumed the biggest participation in the financially most attractive forms of cooperation. Towns and municipalities in the South Bohemian Region are the least engaged in cross-border impulse centres $(0.14 \%)$, Association of Local Governments of the Czech Republic (3.67\%) and Euro-regions (4.27\%), and municipalities are not engaged at all in European Groupings for Territorial Cooperation. Given the identical historical development, the results of the engagement of the municipalities in the South Bohemian Region in cooperation of municipalities can be roughly generalised also in relation to the other regions of the Czech Republic (e.g. micro-regions and local action groups are always the basic forms of cooperation). Nevertheless, it is necessary to point out potential partial differences as each region is a sui generis region due to its qualities and possibilities. This is apparent for example in the engagement in the National Healthy Cities Network of the Czech Republic - it was a less common means of cooperation in the South Bohemian Region both in 2007 and 2014, while the whole regions are engaged elsewhere (South Moravian Region, Liberec Region, MoravianSilesian Region, Plzeň Region, Highlands Region and Prague Region). However, differences in cooperation of municipalities with subjects of other countries are the biggest ones. Due to their different geographical locations, every region has different starting conditions, which contrary to other means of cooperation of municipalities, cannot be influenced. The regions can differ in the width and the depth of the cooperation they engage in, but not in the basic principles of cooperation of municipalities shown in the pyramidal model of the respective forms of cooperation. 

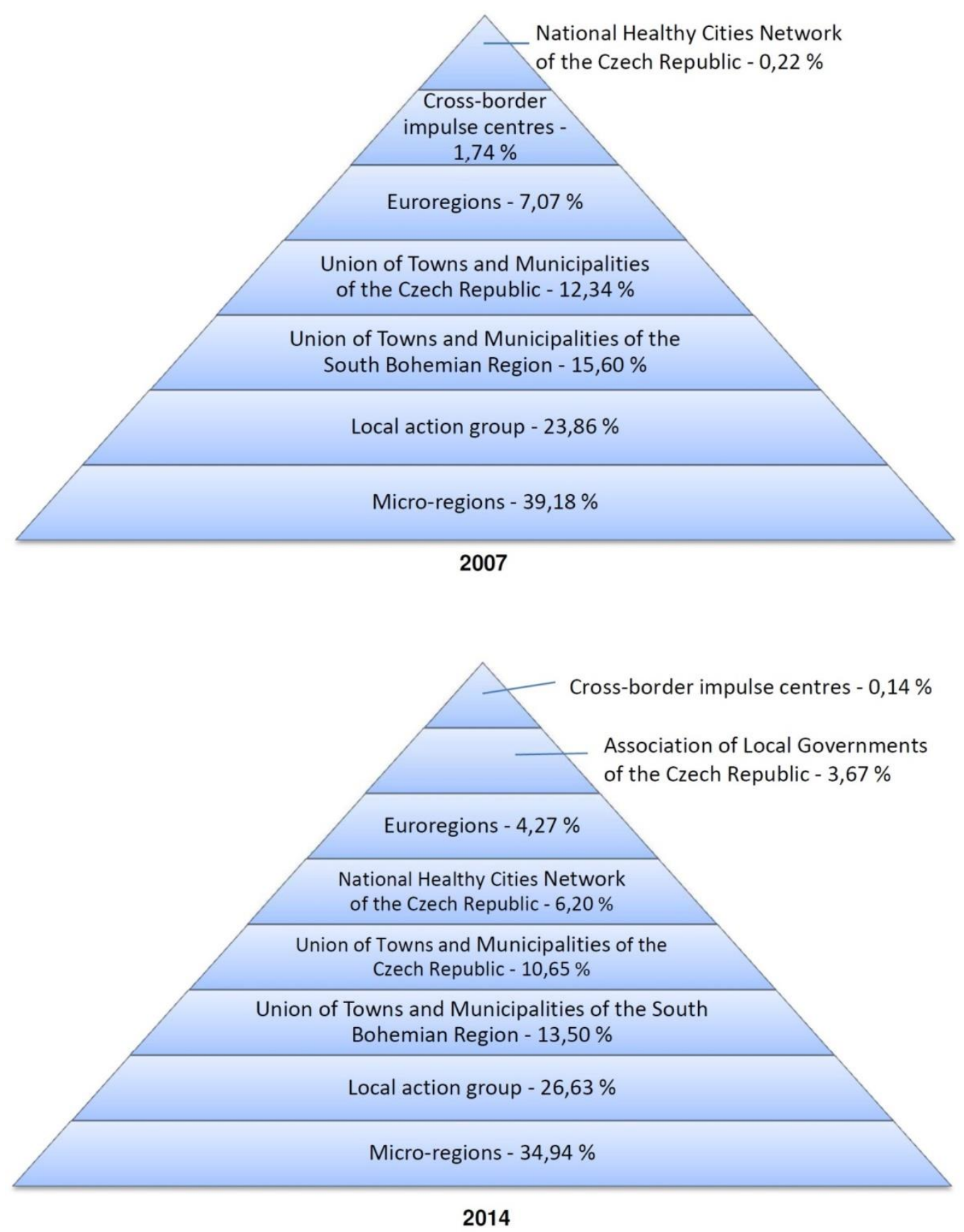

Fig 2. Means of cooperation of municipalities in the South Bohemian Region (2007 and 2014). Source: Author's own research

Cooperation of municipalities changed a lot during the programming period of 2007-2013 and it gradually aims for $100 \%$ saturation of the region (only 11 municipalities are currently not engaged, while it was 26 municipalities in 2007). Besides other things, reduction in the size of military areas should cause another shift in the future. The decrease of $-57.69 \%$ in the number of unengaged municipalities was caused mainly by the development of the means of cooperation within microregions and the development of local action groups in the district of Jindrichưv Hradec, which is among the economically weakest and as regards cooperation of municipalities, among the most problematic regions (out of 13 municipalities which were not engaged in 2007, the number of municipalities dropped to 5 here in 2014). As regards the causes of being not engaged, the abovementioned 11 as yet unengaged municipalities in 2014 can be divided into 2 , or rather 3 categories: 
> suburbanized municipalities near large towns - České Budějovice, Jindřichův Hradec and Soběslav (Dobrá Voda u Českých Budějovic, Nová Včelnice, Staré Hodějovice, Zvěrotice - the average number of residents is 1596),

$>$ small municipalities with insufficient administrative, financial, personal and technical background (Bednárec, Hadravova Rosička, Hájek, Vlčetínec, Vrbice, Žd'ár - the average number of residents is 68),

$>$ municipalities in a military area or military training area (Boletice) - this category can be considered separate for the purposes of more precise mapping of the area - these municipalities are independent territorial units but they should not be placed among municipalities.

Regions with the currently lowest participation of municipalities in cooperation among municipalities are administrative districts of municipalities with extended competence Týn nad VItavou and the Soběslav, which was partially caused, e.g., by the termination of some LAGs or too much bureaucracy in implementing some forms of cooperation of municipalities. Paradoxically, however, these regions can be considered as not very promising but not as the most problematic regions in the South Bohemian Region. Based on results of a research, 2 main problem areas were defined within the South Bohemian Region: The České Budějovice Region - the immediate surroundings of České Budějovice; and the Jindřichův Hradec Region especially in the peripheral regions on the border with the Vysočina Region, which confirms hypothesis No.2 regarding the uneven development of regions.

\section{Conclusion}

Based on the example of the South Bohemian Region, the analyses and research which have been done prove and confirm the significance and the future potential of the development of cooperation of municipalities. However, it is essential to point out that it will most likely not reach the dynamics of the period between 2007 and 2014, when it attacked the growth of almost 20\% of all statistically measurable forms of cooperation of municipalities. This dynamic growth was caused by several internal and external reasons, such as the resources from the European funds and the initiative of the Committee of the Regions, approval of the new civil code, differentiation of the interests of small and large municipalities, certain modernity of environmental topics and so on.

As regards the respective forms and means of cooperation of municipalities defined by the author - thanks to the cooperation within micro-regions, inter-municipal cooperation dominated on a regional level since late 1990 s with a share of over $50 \%$. Nowadays, however, these days in the South Bohemian Region on the level of $30-40 \%$ certain stabilization and balancing of the significance / engagement of municipalities into 3 major cooperation structures occurs (intermunicipal cooperation on a regional level, with subjects in the territory, national structures of intermunicipal cooperation), while cooperation of municipalities with subjects of other countries is on the significant decline. Its representation within cooperation of municipalities dropped to only $4.41 \%$, which was helped by the fact that in spite of long-term system support of the EU, crossborder impulse centres ceased to exist and the interest to participate in Euro-regions dropped.

Based on the respective means of cooperation, National Healthy Cities Network of the Czech Republic saw the biggest growth, amounting to $+3,275 \%$. Participation in local action groups, where the total of 580 municipalities are already involved, increased by $32.12 \%$. Although less dynamic, this growth is much more important, as it significantly contributes to the development of rural areas and their absorption abilities, mainly as regards financial resources from the national and European sources. A great many means of cooperation of municipalities reached their possibilities and no further growth can be expected in this respect - e.g. Union of Towns and Municipalities of the South Bohemian Region, Union of Towns and Municipalities of the Czech Republic and means of cooperation within micro-regions where the changes in the engagement of municipalities have been in the range of several percent in the past years. When engaging in the structures of cooperation of municipalities, municipalities do not act in a random way but proceed from the basic forms of cooperation (most often within micro-regions) to the higher forms 
of cooperation (local $\rightarrow$ national $\rightarrow$ global/international level). At first, cooperation among neighbouring municipalities is formed, then this cooperation is extended and other non-profitable and entrepreneurial subjects are engaged. Once the identical cooperation structures develop in multiple regions, various cooperations can be formed on a national level. Cooperation with subjects of other countries can be considered as the top means of cooperation. This cooperation can have an individual or institutional character.

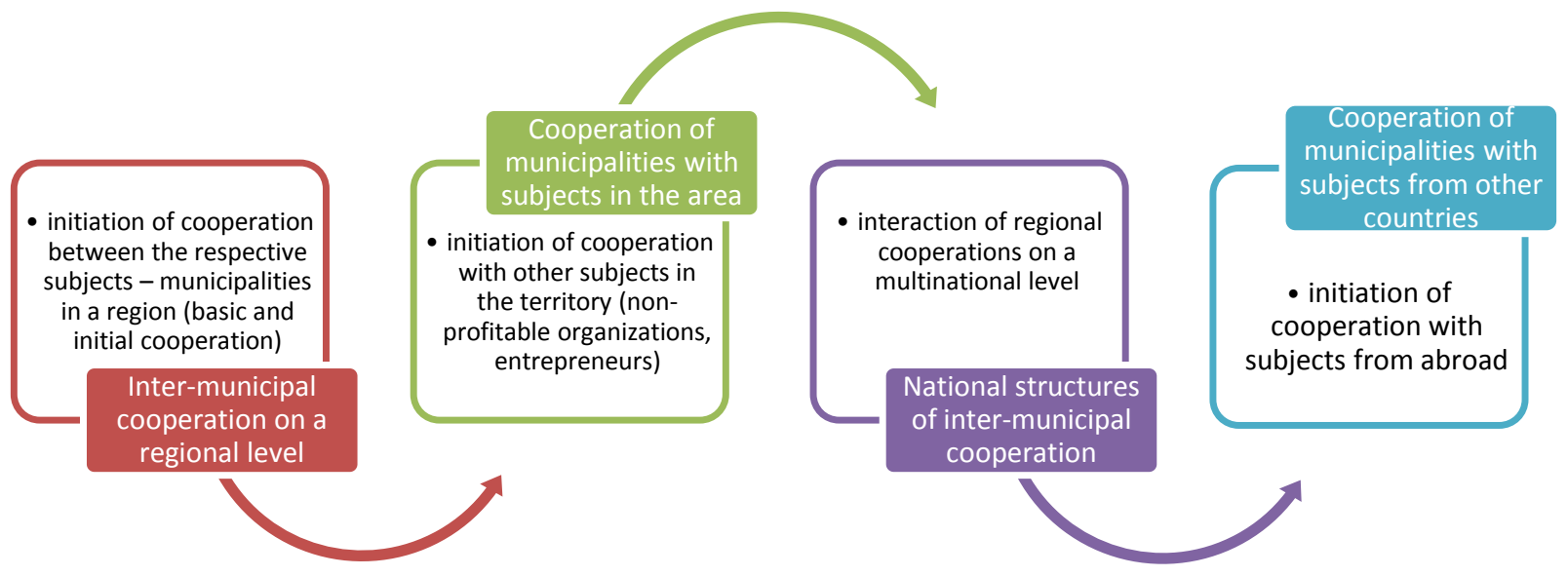

Fig 3. The process of the formation and the development of cooperation of municipalities. Source: Author's own research

More detailed information for the purpose of deeper analysis of cooperation of municipalities is provided by the existence of the cooperation coefficient $\mathrm{C}_{\mathrm{c}}$, which can be determined both on the level of the whole region and on the level of districts, the area of municipalities with extended competence or the respective towns and municipalities. If we said that the number of municipalities engaged in municipal cooperation rose by almost $20 \%$, this growth can also be interpreted using $C_{C}$, which grew from the value of 2.95 in 2007 to the value of 3.50 in 2014 . While in 2007 the most frequent value was the value of $C_{C}=2$, it was already the value of 4 in 2014 and $29.7 \%$ of all municipalities had it. Except for the administrative district of the municipality with extended competence Trhové Sviny, the coefficient $C_{C}$ in the monitored period grew in all regions of the South Bohemian Region. The biggest changes were recorded on the north-east inner periphery of the region and on the south-west border periphery of the region. There were minimum changes of the cooperation of municipalities in the regions neighbouring on the Central Bohemian Region. Administrative district of the municipality with extended competence Týn nad Vitavou and the Soběslav district are regions currently with the lowest engagement in municipal cooperation. In the past years, this was caused, e.g., by the fact that some local action groups ceased to exist and by pure formalism practised during the implementation of some means of cooperation of municipalities. Paradoxically, these regions can be described as not very prospective, yet not the most problematic regions of the South Bohemian Region. Based on the research results, 2 main problem areas of the region were delimited in the South Bohemian Region: the district of České Budějovice - the immediate surroundings of České Budějovice and the district of Jindřichův Hradec - mainly in peripheral regions bordering on the Highland Region. This delimitation is based on the value of $\mathrm{C}_{c}$ but it also considers the development of the respective municipalities or smaller territorial units in these regions, in which $\mathrm{C}_{c}$ continuously decreases, although it generally grows. The statutory town of České Budějovice is a flagrant example of this development. In spite of its size, it cannot be considered as a centre of the regional development in the central areas of the region. There is a large number of municipalities in the district of Jindřichův Hradec which are engaged to a minimum extent or are not engaged at all in any form of cooperation. Moreover, there is no natural leader represented by an active large or small municipality which would initiate the formation of cooperation of municipalities and its dissemination in the surrounding areas. If we add limited possibilities to participate in cross-border 
cooperation and the neighbourhood of economically substandard and weak areas of the Highland Region, we get a combination of many adverse factors at the same time, also confirmed by the method of scaling. Their influence will have a long-term negative impact in this region in the future. The solution of this situation could be either more active engagement of the town of Jindřichův Hradec, Nová Bystřice and other larger towns or targeted financial stimulation of the area which is complicated by the border of two regions - the South Bohemia Region and the Highland Region.

Regions surrounding municipalities with high engagement in cooperation of municipalities stand on an entirely opposite pole. They include mainly municipalities with $\mathrm{C}_{\mathrm{c}}=7$ and 8 and their total number in the South Bohemian Region is 15 . Only Strakonice has the coefficient $C_{c}=8$, this town being historically one of the most active towns, not just in this area of the South Bohemian Region, but in the whole of the Czech Republic. The first place synergically shows itself in the whole district which is among the 3 most successful districts of the region, along with the districts of Český Krumlov and Třeboň, as regards cooperation. Together with Strakonice, Dačice, Prachatice and Třeboň, it can be considered as the real centres and "engines" of the development. We could find a wide range of inspiring examples of good practice which helped achieve the $4^{\text {th }}$ development degree of decreasing disparities between the regions. The particular form of cooperation of municipalities has no uniform character in the regions and it reflects a large number of local, historical and other specifics and connections. While micro-regional means of cooperation dominate for example in the districts of Dačice, Písek, Soběslav and Týn nad Vltavou, local action groups dominate in the districts of České Budějovice, Prachatice and Vodňany.

Cooperation of municipalities is not a universal remedy for all maladies that municipalities suffer from. It requires a big effort, competent leaders and the engagement of other subjects which can participate in the development of the region. Cooperation is only a potential option for all large and small municipalities, which they could, but do not have to use. Unfortunately, although various forms of cooperation of municipalities have been used for many years, it is still an underestimated element of regional development in the Czech Republic, enabling municipalities to overcome their various handicaps in more or less formalised cooperation structures.

\section{Acknowledgement}

The publishing of the paper is supported by the Internal Grant Agency of College of European and Regional Studies, project Nr. 1/2015 "Importance of Inter-municipal Cooperation on the Example of a Selected Area in the South Bohemian Region".

Academic references

[1] Bartholomeeussen, T. (2001). Spoločná věc (rozvoj - partnerstvo a medziobecná spolupráca). Bratislava: Phare 9808-04-01/007, Open Society Foundation.

[2] Bel, G., Fageda, X., Mur, M. (2013). Why do municipalities cooperate to provide local public services? An empirical analysis. Local Government Studies, 39(3), 435-454. Doi: 10.1080/03003930.2013.781024.

[3] Bel, G., Warner, M. E. (2015). Inter-municipal cooperation and costs: Expectations and evidence. Public Administration, 93(1), 52-67. Doi: 10.1111/padm.12104.

[4] Bennett, R. (1993). Local Government in the New Europe. London: Belhaven.

[5] Bennett, R. (1997). Local Government in post-socialist cities. Budapest: Local Government and Public Service Reform Initiative.

[6] Binek, J. et al. (2011). Synergie ve venkovském prostoru - Paradoxy rozvoje venkova. Brno: GaREP.

[7] Blažek, B. (2004). Venkovy: anamnéza, diagnóza, terapie. Brno: Era. 
[8] Denters, B. et al. (2016). Inter-municipal cooperation: a democratic deficit? Available at: https://www.utwente.nl/en/bms/pa/staff/boogers/publications/denters-klok-ipsa-2016final.pdf.

[9] Dušek, J. (2010). Faktory regionálního růstu a rozvoje (se zaměřením na spolupráci měst a obcí v Jihočeském kraji). České Budějovice: Vysoká škola evropských a regionálních studií.

[10] Dušek, J. (2013). European Grouping of Territorial Cooperation as a Way of Cross-Border Regional Cooperation Within the European Union. In Klímová, V. \& Žítek, V., eds., $16^{\text {th }}$ International Colloquium on Regional Sciences (pp. 329-336). Brno: Masaryk University. Doi: 10.5817/CZ.MUNI.P210-6257-2013-40.

[11] Frick, H. J. \& Hokkeler, M. (2008). Interkommunale Zusammenarbeit - Handreichung für die Kommunalpolitik. Bonn: Friedrich-Ebert-Stiftung KommunalAkademie.

[12] Galvasová, I. et al. (2007). Spolupráce obcí jako faktor rozvoje. Brno: Georgetown.

[13] Gillette, C. P. \& Skeelb, D. A., Jr. (2016). Governance reform and the judicial role in municipal bankruptcy. Yale Law Journal 125(5), 1150-1237.

[14] Halachmi, A. \& Boorsma, P. B. (2013). Inter and Intra Government Arrangements for Productivity: An Agency Approach. Berlin: Springer Science \& Business Media.

[15] Hazakis, K. \& loannidis, P. G. (2014). The Impact of the Local Government Institutional Framework on the Distribution of Intergovern-mental Grants: Greek Republic as a Case Study. European Journal of Spatial Development, 55, 1-26.

[16] Holeček, J. et al. (2009). Obec a její rozvoj v širších souvislostech. Brno: GaREP.

[17] Huber, T. (2014). Interkommunale Zusammenarbeit im Rahmen der (Teil-) Flächennutzungsplanung Windkraft: als Konsequenz der Änderung des badenwürttembergischen Landesplanungsgesetzes. Kehl: Hochschule für öffentliche Verwaltung.

[18] Hulst, R. \& van Montfort, A. (2007). Inter-Municipal Cooperation in Europe. Dordrecht: Springer. Doi: 10.1007/1-4020-5379-7.

[19] Keating, M. (1995). Size, Efficiency and Democracy: Consolidation, Fragmentation and Public Choice. In Judge, D., Stoker, G., Wollman, H., eds., Theories of Urban Politics. London: Sage Publications.

[20] Klein, B. (2012). Kommunale Kooperationen zwischen innerstaatlichem Organisationsakt und Markt: ein Beitrag zur Bestimmung der Reichweite des europäischen Vergaberechts dargelegt am Beispiel der Vergabekoordinierungsrichtlinie, des Vergabeprimärrechts und des deutschen Kartellvergaberechts. Göttingen: V\&R Unipress GmbH.

[21] Klimovský, D., Mejere, O., Mikolaityte, J., Pinterič, U. \& Saparniene, D. (2014). Intermunicipal cooperation in Lithuania and Slovakia: Does size structure matter? Lex Localis 12(3), 643-658. Doi: 10.4335/12.3.643-658(2014).

[22] Lacerda, N. \& Ribeiro, S. (2014). Limits of metropolitan management and barriers to intermunicipal cooperative governance in Brazil. Eure 40(121), 171-201. Doi: $10.4067 /$ S0250-71612014000300009.

[23] Leemans, A. F. (1970). Changing patterns of local government. The Hague: International Union of Local Authorities.

[24] Lidström, A. (1998). The Comparative Study of Local Government Systems - A Research Agenda. Journal of Comparative Policy Analysis, 1(1), 97-115. Doi: $10.1080 / 13876989808412617$.

[25] Nelles, J. (2013). Cooperation and capacity? Exploring the sources and limits of city-region governance partnerships. International Journal of Urban and Regional Research, 37(4), 1349-1367. Doi: 10.1111/j.1468-2427.2012.01112.x. 
[26] Perlín, R. (1999). Venkov, typologie venkovského prostoru. In Malý, F. \& Viktoriová, B., eds., Česká etnoekologie. Praha: Cargo.

[27] Rakar, I., Tičar, B. \& Klun, M. (2015). Inter-municipal cooperation: Challenges in Europe and in Slovenia. Transylvanian Review of Administrative Sciences, 45, 185-200.

[28] Richter, M. (2013). Regionalisierung und interkommunale Zusammenarbeit: Wirtschaftsregionen als Instrumente kommunaler Wirtschaftsförderung. Berlin: SpringerVerlag.

[29] Rose, J. (2010). L'aménagement du territoire, la coordination intermunicipale et les relations centrales-locales en contexte métropolitain. Québec: Université du Québec - École nationale d'administration publique.

[30] Ryšavý, I. (2006). Společenství obcí ještě vzbudí diskusi, ale pro venkov je jednou ze šancí. Available at: http://moderniobec.inned.cz/c1-17516690-spolecenstvi-obci-jeste-vzbudidiskusi-ale-pro-venkov-je-jednou-ze-sanci.

[31] Sager, F. (2005). Metropolitan institutions and policy coordination: The integration of land use and transport policies in Swiss urban areas. Governance, 18(2), 227-256. Doi: 10.1111/j.1468-0491.2005.00274.x.

[32] Sciandra, L. (2011). Partecipazioni comunali e intrecci economico-finanziari: criticità e misurazione. Politica Economica, 27(3), 375-412. Doi: 10.1429/36594.

[33] Schnabel, F. (2012). Formy meziobecní a regionální spolupráce v Německu. Available at: http://moderniobec.cz/formy-meziobecni-a-regionalni-spoluprace-v-nemecku.

[34] Schulitz, A. \& Knoblauch, B. (2011). Interkommunale Kooperation schrumpfender Kleinstädte: Analyse der Chancen und Grenzen für schrumpfende Kleinstädte im ländlichen Raum. München: AVM - Akademische Verlagsgemeinschaft München.

[35] Sørensen, R. J. (2007). Does Dispersed Public Ownership Impair Efficiency? The Case of Refuse Collection in Norway. In Public Administration, 85(4), 1045-1058. Doi: 10.1111/j.1467-9299.2007.00681.X.

[36] Swianiewicz, P., ed., (2002). Consolidation or Fragmentation? The Size of Local Governments in Central and Eastern Europe, Local Government and Public Service Reform Initiative. Budapest: Open Society Institute.

[37] Teles, F. (2016a). Local governance and intermunicipal cooperation. New York: Palgrave Macmillan. Doi: $10.1057 / 9781137445742$.

[38] Teles, F. (2016b). Local government and the bailout: Reform singularities in Portugal. European Urban and Regional Studies, 23(3), 455-467. Doi: 10.1177/0969776413517249.

[39] Urbanová, M. (2015). Malá města Středočeského kraje jako aktéři meziobecní spolupráce. Acta Politologica, 7(1), 79-89.

[40] Vajdová, Z., Čermák, D. \& Illner, M. (2006). Autonomie a spolupráce: důsledky ustavení obecního zřízení v roce 1990. Praha: Sociologický ústav AV ČR.

[41] Wiberg, U. \& Limani, I. (2015). Intermunicipal collaboration - a smart alternative for small municipalities? Scandinavian Journal of Public Administration, 19(1), 63-82.

[42] Wokoun, R. et al. (2008). Regionální rozvoj (Východisko regionálního rozvoje, regionální politika, teorie, strategie a programování). Praha: Linde.

[43] Žárska, E. (2007). Komunálna ekonomika a politika. Bratislava: Ekonóm.

Other sources

[44] Czech Statistical Office. (2013a). Počet obcí podle krajů (stav k 1.1.). Available at: http://www.czso.cz/cz/cr_1989_ts/0201.xls. 
[45] Czech Statistical Office. (2013b). Počet obcí a obyvatel v jednotlivých velikostních skupinách obcí podle výsledků sčitání lidu $v$ letech 1921-2001. Available at: http://www.czso.cz/csu/2012edicniplan.nsf/t/B5001FC4FC/\$File/4032120114.xls.

[46] Czech Statistical Office. (2015a). Vývoj počtu obcí v České republice podle krajů (stav k 1.1.). Available at: https://www.czso.cz/documents/10180/20551237/ 32018115_0201.xIsx/cfdeb0ee-b8ff-4fa4-8c7d-649944f31460?version=1.0.

[47] Czech Statistical Office. (2015b). Počet obyvatel v obcích České republiky k 1.1.2015. Available at: https://www.czso.cz/documents/10180/20556287/1300721503.xlsx/ 75b39cc7-7aa3-4f31-a6e3-018bb06a5f83?version=1.1. 